\title{
Reverse transcription polymerase chain reaction (RT-PCR) used for the detection of Taura Syndrome Virus (TSV) in experimentally infected shrimp
}

\author{
L. M. Nunan*, B. T. Poulos, D. V. Lightner \\ Department of Veterinary Science and Microbiology, University of Arizona, Tucson, Arizona 85721, USA
}

\begin{abstract}
Taura Syndrome Virus (TSV) has adversely affected the shrimp culture industries of the Americas. First recognized in 1992, this viral agent has spread throughout the shrimp growing regions of South and Central America to become established in North America in the short span of 5 yr. Diagnostic methods for TSV include histopathology, bioassay using susceptible Penaeus vannamei as the indicator species and in situ hybridization with TSV specific complimentary DNA (CDNA) gene probes. An additional method for detecting TSV is through the use of reverse transcription polymerase chain reaction (RT-PCR). Two oligonucleotide primers were selected using the sequence information from a cloned cDNA segment of the TSV genome. The primers, designated 9195 and 9992, used in the RT-PCR procedure amplify a 231 base pair (bp) fragment of the CDNA. Using the RT-PCR technique, TSV has been detected in the hemolymph of $P$. stylirostris and $P$. vannamei with experimentally induced TSV infections.
\end{abstract}

KEY WORDS: RT-PCR - Taura Syndrome Virus (TSV) · Penaeid shrimp

\section{INTRODUCTION}

The shrimp farming industries of the Americas have been adversely affected by epizootics due to viral pathogens. Taura Syndrome Virus (TSV) has had an enormous negative impact on shrimp culture in the Western Hemisphere (Lightner 1995). First recognized in commercial penaeid shrimp farms located near the mouth of the Taura River in the Gulf of Guayaquil, Ecuador in mid-1992 (Jimenez 1992), this viral pathogen has spread throughout South and Central America into North America in the short span of $5 \mathrm{yr}$ (Lightner 1996). TSV has been the causative agent of economically disastrous epizootics in Penaeus vannamei, causing mass mortalities of 40 to $95 \%$ in affected postlarval and juvenile populations (Lightner et al. 1995, 1997, Brock et al. 1995, 1997). Other American species, including $P$. setiferus, $P$. schmitti and $P$. stylirostris, are less seriously affected by TSV (Hasson et al. 1995, Overstreet et al. 1997).

·E-mail:Imn@u.arizona.edu
TSV causes 3 distinguishable disease phases in infected shrimp. The peracute/acute phase of the disease is characterized by moribund shrimp displaying an overall pale reddish coloration caused by the expansion of the red chromatophores. Shrimp in this phase usually die in the process of molting. If the shrimp survive through the peracute/acute phase of TSV infection, the recovery phase begins. Multifocal, melanized cuticular lesions are the major distinguishing characteristic of the recovery phase (Lightner 1996). In the chronic phase of TSV infection, infected shrimp appear and behave normally, but remain persistently infected, perhaps for life (Hasson et al. 1997b).

The current diagnostic and detection methods for TSV include histopathology, in situ hybridization and bioassay (Lightner 1996). Most recently, reverse transcription polymerase chain reaction ( $R T-P C R$ ) has been developed to detect TSV in the hemolymph of infected shrimp. Diagnostic histopathology in shrimp with acute, natural or experimental TSV infections display multifocal areas of necrosis of the cuticular epithelium and subcutis. Lesions are characterized by 
the presence of variably sized eosinophilic to basophilic cytoplasmic inclusion bodies creating a peppered' or 'buckshot' appearance which is considered to be pathognomonic for this disease (Lightner et al. 1997). In situ hybridization assays, employing a nonradioactively digoxigenin (DIG)-labeled cDNA probe, provide excellent sensitivity when used on properly fixed tissues (Hasson et al. 1997a). A bioassay diagnostic method, using juvenile specific pathogen-free (SPF) Penaeus vannamei (Wyban et al. 1992) as the indicator species for TSV, can enhance the virus from asymptomatic carrier shrimp (Brock et al. 1995, Lightner 1996).

TSV is a positive sense single stranded RNA virus, tentatively classified in the Picornaviridae family (Hasson et al. 1995, Lightner 1996, Bonami et al. 1997). RT-PCR must first convert the ssRNA to cDNA through reverse transcription. Using sequence information from cloned cDNA segments of the TSV genome (Mari et al. 1998) 2 primers were selected from a cDNA TSV clone. These 18 mer primers amplify a 231 base pair (bp) fragment of the TSV genome.

\section{MATERIALS AND METHODS}

Indicator shrimp. Penaeus stylirostris weighing approximately $4.5 \mathrm{~g}$, originating from a commercial shrimp hatchery in Venezuela, and SPF P. vannamei (Wyban et al. 1992, Carr et al. 1996), from the Oceanic Institute, Hawaii, average weight of $4.0 \mathrm{~g}$, were reared from post larvae to the juvenile stage, using the methods described in Williams et al. (1992).

Preparation of inoculum. Whole animal TSVinfected Penaeus vannamei with carapace removed, originating from a shrimp farm in Mexico, were minced and fed per os to SPF, juvenile $P$. vannamei (Wyban et al. 1992), weighing approximately $1 \mathrm{~g}$. The infected shrimp were collected, the carapace removed, minced and homogenized in TN buffer $10.02 \mathrm{M}$ Tris$\mathrm{HCl}, 0.4 \mathrm{M} \mathrm{NaCl}, \mathrm{pH} 7.4)$. Following centrifugation at $1000 \times g$ for $10 \mathrm{~min}$, the supernatant fluid was diluted $1: 10$ with $2 \% \mathrm{NaCl}$. Ten $P$. stylirostris $(4.5 \mathrm{~g})$ and $20 P$. vannamei $(4.0 \mathrm{~g})$ were inoculated with $0.1 \mathrm{ml}$ of inoculum, by injecting dorso-laterally between the tergal plates of the third and fourth abdominal segments into the underlying muscle.

RNA template. The hemolymph from TSV-infected Penaeus vannamei was collected from moribund shrimp during the acute phase of the bioassay experiment. The hemolymph from the surviving shrimp, which entered into the chronic stage of infection, was also collected. A $1 \mathrm{ml}$ syringe fitted with a $25 \mathrm{~g}$ needle was inserted into the sinus located beneath the coxa segment of the third pereiopod. Approximately 0.2 to
$0.5 \mathrm{ml}$ of the hemolymph was obtained from each specimen. The hemolymph from the TSV-infected $P$. stylirostris was collected by the same procedure as was used for the $P$. vannamei. In this bioassay, there were no acute phase mortalities. Samples were collected over a period of $56 \mathrm{~d}$.

Day 0 hemolymph sampled from the Penaeus vannamei and $P$. stylirostris was used as the negative control in the appropriate experiments. The hemolymph was put on ice and stored in a $-70^{\circ} \mathrm{C}$ freezer until needed for the RT-PCR reactions. All PCR assays used hemolymph directly as the RNA template, extraction of the RNA was not necessary.

RT-PCR primers. Two oligonucleotide primers were used in the RT-PCR amplification procedure. Primers designated as 9195 and 9992 (Fig. 1) amplify a 231 bp sequence of the TSV genome. The primers were chosen using the Primer 2, Primer Designer Program Version 2.2 (Scientific and Educational Software, Stateline, PA) from the cDNA sequence information from a TSV P15 clone (Mari et al. 1998). These primers were synthesized at the University of Arizona, Arizona Research Laboratory, Division of Biotechnology Macromolecular Structures Facility, using a 4 column ABI 394A DNA synthesizer. After purification, the oligonucleotide primers were dispensed into aliquots and stored at $-70^{\circ} \mathrm{C}$.

Reverse transcription of TSV RNA. The RT-PCR assays were done in solution, using $1.0 \mu \mathrm{l}$ of shrimp hemolymph as the RNA template. The GeneAmp ${ }^{\otimes}$, EZ rTth RNA PCR kit (Perkin Elmer Cetus, Norwalk, CT) was used for all amplification reactions. This enzyme both reverse transcribes the RNA to CDNA and subsequently amplifies the cDNA. The optimized RT-PCR conditions (final concentrations in $50 \mu$ total volume) for detection of TSV in Penaeus vannamei were: primers (0.46 $\mu \mathrm{M}$ each), dNTPs (300 $\mu \mathrm{M}$ each), rTth DNA polymerase $(2.5 \quad U / 50 \mu l)$, manganese acetate $(2.5 \mathrm{mM})$, in $5 \times \mathrm{EZ}$ buffer $(25 \mathrm{mM}$ Bicine, $57.5 \mathrm{mM}$ potassium acetate, $40 \%$ [w/v] glycerol, $\mathrm{pH}$ 8.2). The optimized RT-PCR conditions for detec-

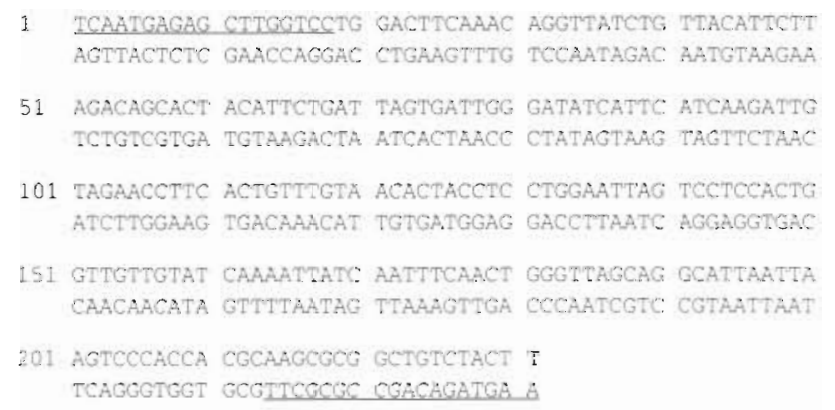

Fig. 1. Sequence of the $231 \mathrm{bp}$ TSV fragment. Underlined portion represents the position of the primers $9195 \mathrm{~F}$ and $9992 \mathrm{R}$ 
tion of TSV in the hemolymph from infected Penaeus stylirostris were the same as for $P$. vannamei, except that the amount of the rTth DNA polymerase was increased to $5.0 \mathrm{U} / 50 \mu \mathrm{l}$. Light mineral oil $(50 \mu \mathrm{l})$ was overlaid on the top of the $50 \mu$ reaction mixtures to prevent evaporation during thermal cycling.

The RNA template and all the reagents were combined and reverse transcription was allowed to proceed at $60^{\circ} \mathrm{C}$ for $30 \mathrm{~min}$, followed by $94^{\circ} \mathrm{C}$ for $2 \mathrm{~min}$, in an automatic DNA Thermal Cycler 480 (Perkin Elmer Cetus, Norwalk, CT). At the completion of reverse transcription, the samples were amplified for 40 cycles under the following conditions: denaturation at $94^{\circ} \mathrm{C}$ for $45 \mathrm{~s}$; annealing/extension at $60^{\circ} \mathrm{C}$ for $45 \mathrm{~s}$. A final extension step for $7 \mathrm{~min}$ at $60^{\circ} \mathrm{C}$ followed the last cycle and the process was terminated in a $4^{\circ} \mathrm{C}$ soak file.

Agarose gel electrophoresis. Following the termination of RT-PCR, the amplified CDNA solutions were drawn off from beneath the mineral oil and placed into clean $0.5 \mathrm{ml}$ microfuge tubes. A $10 \mu \mathrm{l}$ sample of the amplified product was analyzed on a $2.0 \%$ agarose gel (Perkin Elmer Cetus, Norwalk, CT), stained with ethidium bromide $\left(0.5 \mathrm{mg} \mathrm{ml}^{-1}\right)$, and electrophoresed in $0.5 \%$ TBE (Tris, boric acid, EDTA) (Maniatis et al. 1982). A 100 bp DNA ladder (Gibco/BRL, Gaithersburg, MD) was used as a marker. To confirm the specificity of the amplified RT-PCR product, Southern blot analysis (Maniatis et al. 1982) was performed using DIG-labeled cDNA derived from the same cDNA sequence data as the RT-PCR primers. The CDNA was labeled by the random primed labeling procedure according to the manufacturer's protocol (Boehringer Mannheim, Indianapolis, IN).

Histological procedures. Two of the 20 Penaeus vannamei were sampled in a moribund state and their cephalothoracies were preserved in Davidson's AFA (alcohol, formaldehyde and acetic acid) fixative for histopathological examination according to Bell \& Lightner (1988). Two of the $10 \mathrm{P}$. stylirostris were randomly sampled for histological evaluation. Histopathology was carried out by routine procedures (Lightner 1996). Histopathological examination of the processed samples was performed using standard light microscopy.

In situ hybridization. The sample animals that were fixed in Davidson's AFA and embedded in paraffin for histological analysis were also evaluated by in situ hybridization (Bruce et al. 1993, Lightner 1996). A series of consecutive sections, $4 \mu \mathrm{m}$ thick, were mounted onto Superfrost ${ }^{\oplus / P l u s}$ positively charged microscope slides (Fisher Scientific, Pittsburg, PA). These tissue sections were evaluated using the same DIG-labeled probe mixture as was used for the Southern blot confirmation (Maniatis et al. 1982). The in situ procedure for TSV is outlined in detail by Lightner (1996) and Hasson et al. (1997a).

\section{RESULTS}

A $90 \%$ mortality rate was reached 4 d post-infection in the bioassay experiment conducted with Penaeus vannamei (Table 1). One shrimp survived into the chronic phase of TSV infection and was sampled on Day 9. All of the hemolymph samples tested by RTPCR revealed the $231 \mathrm{bp}$ fragment indicative of TSV when analyzed on a $2 \%$ agarose gel (Fig. 2). These fragments were confirmed to be TSV specific by Southern blot analysis (data not shown). Histology confirmed that the experimental shrimp had acute phase TSV infections.

No mortalities were observed following the injection of the TSV inoculum in Penaeus stylirostris (Table 2). Hemolymph was sampled randomly over a period of $56 \mathrm{~d}$. TSV was detected consistently in the hemolymph

Table 1. Detection of TSV in moribund, acute phase or in chronic phase Penaeus vannamei using RT-PCR and histological methods

\begin{tabular}{|lccccc|}
\hline Species & $\begin{array}{c}\text { Date of hemo- Date (post- } \\
\text { lymph draw }\end{array}$ & $\begin{array}{c}\text { No. of } \\
\text { injection) }\end{array}$ & $\begin{array}{c}\text { RT-PCR } \\
\text { samples }\end{array}$ & $\begin{array}{c}\text { Histology } \\
\text { results }\end{array}$ \\
\hline P. vannamei & 18 May 1997 & 0 & 1 & Negative & Negative \\
P. vannamei & 19 May 1997 & 1 & 3 & Positive & Positive \\
P. vannamei & 20 May 1997 & 2 & 2 & Positive & Positive \\
P. vannamei & 21 May 1997 & 3 & 1 & Positive & Not examined \\
P. vannamei & 22 May 1997 & 4 & 1 & Positive & Positive \\
P. vannamei & 27 May 1997 & 9 & 1 & Positive & Positive \\
\hline
\end{tabular}

Table 2. Detection of TSV in randomly sampled Penaeus stylirostris using RT-PCR, routine histology and in situ hybridization

\begin{tabular}{|c|c|c|c|c|c|}
\hline Species & $\begin{array}{l}\text { Date of hemo- } \\
\text { lymph draw }\end{array}$ & $\begin{array}{l}\text { Date (post- } \\
\text { injection) }\end{array}$ & $\begin{array}{c}\text { No. of } \\
\text { samples }\end{array}$ & $\begin{array}{c}\text { RT-PCR } \\
\text { results }\end{array}$ & $\begin{array}{l}\text { Histology \& } \\
\text { in situ results }\end{array}$ \\
\hline P. stylirostris & 29 Sep 1997 & 0 & 1 & Negative & Negative \\
\hline P. stylirostris & 2 Oct 1997 & 3 & 1 & Positive & Not examined \\
\hline P. stylirostris & 6 Oct 1997 & 7 & 2 & Positive & Not examined \\
\hline P. stylirostris & 9 Oct 1997 & 10 & 2 & Positive & Not examined \\
\hline P. stylirostris & 16 Oct 1997 & 17 & 1 & Positive & Negative \\
\hline P. stylirostris & 30 Oct 1997 & 31 & 1 & Negative & Not examined \\
\hline P. stylirostris & 5 Nov 1997 & 37 & 2 & Positive & Negative \\
\hline P. stylirostris & 17 Nov 1997 & 49 & 2 & Negative & Not examined \\
\hline P. stylirostris & 24 Nov 1997 & 56 & 2 & Negative & Not examined \\
\hline
\end{tabular}




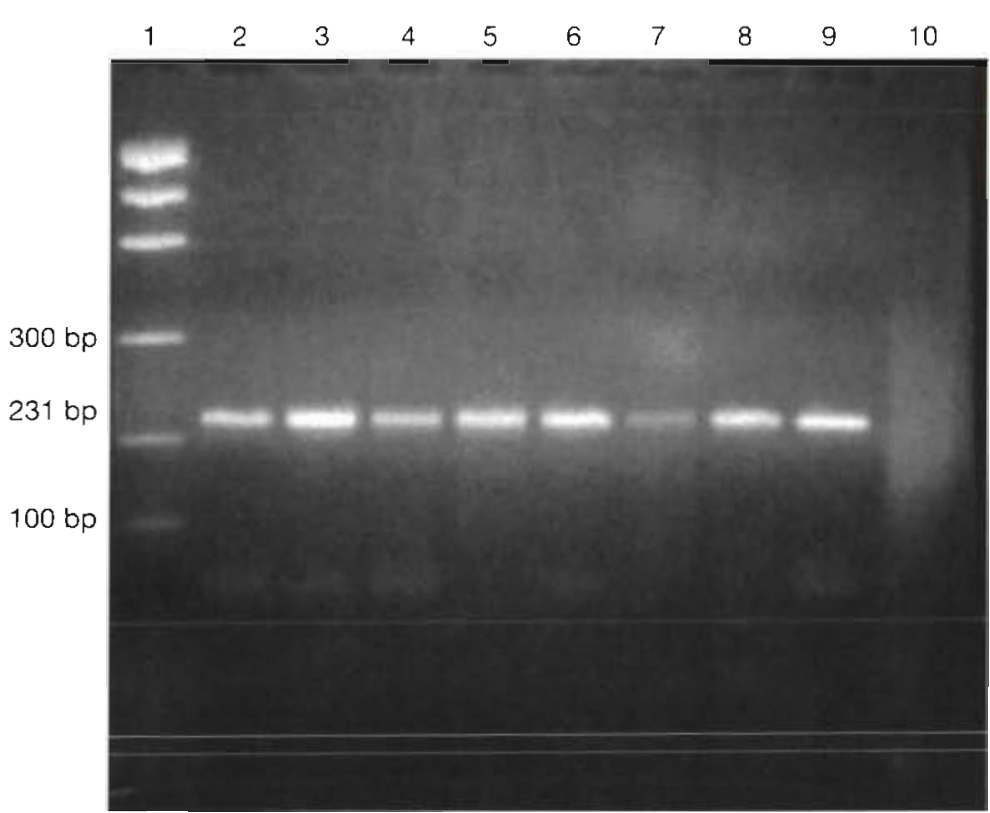

Fig. 2. Agarose electrophoresis gel of RT-PCR products from an RT-PCR assay using the primers 9195 and 9992 . The $231 \mathrm{bp}$ band indicates the presence of TSV. The hemolymph from TSV-infected Penaeus vannamei was used as the RNA template. Lane 1: 100 bp ladder; lanes 2-8: hemolymph from $P$. vannamei bioassay, corresponding to samples listed in Table 1 ; lane 9: positive TSV RT-PCR control; lane 10: Day 0 hemolymph negative RT-PCR control

samples to Day 17. A 31 d sample was negative by RTPCR, but 6 d later (Day 37) 2 hemolymph samples were tested and TSV was once again detected. The next 2 hemolymph samples, taken on Days 49 and 56, were negative.

RT-PCR analysis of the Penaeus stylirostris hemolymph sampled on Day 37 indicated that TSV was present. These shrimp were also evaluated by histology and by in situ hybridization. The results from the 2 latter assays indicated that TSV was not detectable (Table 2). To determine if the RT-PCR reactions were valid, a bioassay using susceptible $P$. vannamei was performed using as the inoculum homogenized tails from the $37 \mathrm{~d}$ samples. The $P$. vannamei in this bioassay experienced a $90 \%$ mortality rate over a 4 d period and were determined TSV positive by histology. The bioassay results demonstrated that TSV was indeed present in the $37 \mathrm{~d}$ sample.

\section{DISCUSSION}

The primary methods for detection of TSV are histology, in situ hybridization and bioassay to enhance the virus. All of these methods are both labor and time consuming. RT-PCR provides an alternative non-lethal and rapid procedure for detection of the virus in hemolymph samples.

All of the experimental assays (RT-PCR, histology, in situ hybridization and bioassay) used to determine TSV infection demonstrated the presence of the virus in the acute phase of the disease. RT-PCR consistently detected TSV in hemolymph, during the acute phase of the bioassay using Penaeus vannamei as the indicator species. In the bioassay which used the less susceptible species P. stylirostris, RT-PCR consistently detected the virus until $17 \mathrm{~d}$ postinjection. Although negative on Day 31, a hemolymph sample from Day 37 indicated the presence of TSV. The corresponding Davidson's AFA-fixed samples, taken on the same days (Table 2), were determined to be negative for TSV when analyzed by histology and in situ hybridization. With the conflicting results from the RT-PCR assay in which TSV was detected, and the histology and in situ hybridization assays which indicated that TSV was not present, a bioassay using TSV susceptible $P$. vannamei became necessary to determine if, in fact, the shrimp were carriers of the virus. The confirmatory bioassay demonstrated the presence of TSV in the shrimp that were sampled on Day 37. In this study, RT-PCR was found to be a more sensitive assay when compared to histology or in situ hybridization for shrimp which have entered the chronic phase of this disease.

Presently, the limitations of detection of TSV by RT-PCR is approximately $14 \mathrm{~d}$ post-injection. Further work will concentrate on determining the length of time in which shrimp can carry TSV and remain infectious. Additional RT-PCR work will attempt to develop methods for using alternative RNA templates such as tissue homogenates in an assay with greater sensitivity in order to detect TSV in shrimp which may be asymptomatic carriers of the disease.

Acknowledgements. Funding for this research was provided by the Gulf Coast Research Laboratory Consortium Marine Shrimp Farming Program, Cooperative State Research, Education, and Extension Service (CSREES), U.S. Dept of Agriculture under Grant No. 88-38808-3320 and the National Sea Grant Program. U.S. Dept of Commerce under Grant No. NA56RG0617, and a special grant from the National Fisheries Institute.

\section{LITERATURE CITED}

Bell TA, Lightner DV (1988) A handbook of normal penaeid shrimp histology. World Aquaculture Society, Baton Rouge, LA, p 1-114 
Bonami JR, Hasson KW, Mari J, Poulos BT, Lightner DV (1997) Taura syndrome of marine penaeid shrimp: characterization of the viral agent. J Gen Virol 78:313-319

Brock JA, Gose R, Lightner DV, Hasson KW (1995) An overview on Taura syndrome, an important disease of farmed Penaeus vannamei. In: Browdy CL, Hopkins JS (eds) Swimming through troubled water Proceedings of the special session on shrimp farming, Aquaculture '95. World Aquaculture Society, Baton Rouge, LA, p 84-94

Brock JA, Gose RB, Lightner DV, Hasson K (1997) Recent developments and an overview of Taura syndrome of farmed shrimp in the Americas. In: Flegel TW, Hopkins IH (eds) Disease in Asian aquaculture III. Fish Health Section Asian Fisheries Society, Manila, p 275-283

Bruce LD, Redman RM, Lightner DV, Bonami JR (1993) Application of gene probes to detect a penaeid shrimp baculovirus in fixed tissue using in situ hybridization. Dis Aquat Org 17:215-221

Carr WH, Sweeney JN, Nunan L, Lightner DV, Hirsch HH, Reddington JJ (1996) The use of an infectious hypodermal and hematopoietic necrosis virus gene probe serodiagnostic field kit for the screening of candidate specific pathogen-free Penaeus vannamei broodstock. Aquaculture $147: 1-8$

Hasson KW, Lightner DV, Poulos BT, Redman RM, White BL, Brock JA, Bonami JR (1995) Taura syndrome in Penaeus vannamei: demonstration of a viral etiology. Dis Aquat Org 23:115-126

Hasson KW, Hasson J, Aubert H, Redman RM, Lightner DV (1997a) A new RNA-friendly fixative for the preservation of penaeid shrimp samples for virological detection using cDNA genomic probes. J Virol Methods 66:227-236

Hasson KW, Redman RM, Mari J, Lightner DV (1997b) Lesion development in Penaeus vannamei juveniles infected with Taura syndrome virus: determination by in-situ hybridization with TSV-specific genomic probes. World Aquaculture ' 97 Book of Abstracts. Seattle, WA, p 204-205

Jimenez R (1992) Sindrome de Taura (Resumen). Acuacultura Ecuador 1:1-16

Editorial responsibility: Larry Vaughan,

Dublin, Ireland
Lightner DV (1995) Taura syndrome: an economically important viral disease impacting the shrimp farming industries of the Americas including the United States. In: Proceedings of the United States Animals Health Association. Reno, NV, p 1-12

Lightner DV (1996) A handbook of shrimp pathology and diagnostic procedures for diseases of cultured penaeid shrimp. World Aquaculture Society, Baton Rouge, LA

Lightner DV, Redman RM, Hasson KW, Pantoja CR (1995) Taura syndrome in Penaeus vannamei (Crustacea: Deca. poda): gross signs, histopathology and ultrastructure. Dis Aquat Org 21:53-59

Lightner DV, Redman RM, Poulos BT, Nunan LM, Mari JL, Hasson KW, Bonami JR (1997) Taura syndrome: etiology, pathology, hosts and geographic distribution, and detection methods. In: New approaches to viral diseases of aquatic animals. Kyoto, Japan, p 190-205

Maniatis T, Fritsch EF, Sambrook J (1982) Molecular cloning a laboratory manual. Cold Spring Harbor Laboratory, Cold Spring Harbor, NY

Mari J, Bonami JR, Lightner DV (1998) Taura syndrome of penaeid shrimp: cloning of the viral genome fragments and development of gene probes. Dis Aquat Org 33(1): $11-17$

Overstreet RM, Lightner DV, Hasson KW, Mcllwain S, Lotz JM (1997) Susceptibility to Taura Syndrome Virus of some penaeid shrimp species native to the Gulf of Mexico and the southeastern United States. J Invertebr Pathol 69: $165-176$

Williams RR, Dehdashti B, Lightner DV (1992) Performance of an aquatic multispecies system in evaluating the effects of a model microbial pest control agent on nontarget organisms. J Toxicol Environ Health 37:247-264

Wyban JA, Swingle JS, Sweeney JN, Pruder GD (1992) Development and commercial performance of high health shrimp using specific pathogen free (SPF) broodstock Penaeus vannamei. In: Wyban $J$ (ed) Proceedings of the Special Session on Shrimp Farming. World Aquaculture Society, Baton Rouge, LA, p 254-259

Submitted: April 21, 1998; Accepted: July 17, 1998 Proofs received from author(s): September 25, 1998 